\title{
PENGARUH KOMPENSASI FINANSIAL DAN NON FINANSIAL TERHADAP MOTIVASI KERJA DAN KINERJA KARYAWAN BAGIAN LAPANGAN PADA PT UNITED SINDO PERKASA
}

\author{
Novi Indriani ${ }^{1)}$, Adhitomo Wirawan ${ }^{2)}$ \\ 1) Prodi Administrasi Bisnis Terapan, Politeknik Negeri Batam, Batam, Indonesia, \\ Email: novi.indriani015@gmail.com \\ 2) Prodi Administrasi Bisnis Terapan, Politeknik Negeri Batam, Batam, Indonesia, \\ Email: adhitomo@polibatam.ac.id
}

\begin{abstract}
This study aims to identify, both simultaneously and partially between financial and nonfinancial compensation for employees and employees of PT United Sindo Perkasa. This research use Multiple Linear Regression method. The sample in this study used total sampling technique where everyone. The research instrument used is interview and questionnaire. The result of this research is positive financial compensation variable to work motivation. It is seen from $t_{\text {count }}(3,203)$ bigger than $t_{\text {table }}(1,66)$ with significant level $(0,002<0,05)$. The nonfinancial compensation variable has an effect on work, different from 2,461 with significant level $(0,007<0,05)$. Simultaneously, between financial and non-financial tax compensation variable on work motivation, it is seen from $F_{\text {count }}(13,451)$ bigger than $F_{\text {table }}(3.11)$ with significant level $(0,000<0,05)$. Financial compensation variable has a positive effect on employee performance, different from $t_{\text {table }}(1.66)$ with significant level $(0,005<0,05)$. Nonfinancial compensation positive variable on employee performance, different from $t_{\text {table }}(1.66)$ with significant level $(0,023<0,05)$. Adjacent simultaneously between financial compensation variables and non-financial compensation on employee performance, this is seen from $F_{\text {count }}(10,312)$ greater than $F_{\text {table }}(3.11)$ with significant level $(0,000<0.05)$.
\end{abstract}

Keywords: Financial Compensation, Non Financial Compensation, Motivation and Performance

\begin{abstract}
Abstrak
Penelitian ini bertujuan untuk mengetahui pengaruh, baik secara simultan maupun parsial antara kompensasi finansial dan kompensasi non finansial terhadap motivasi kerja dan kinerja karyawan lapangan PT United Sindo Perkasa. Penelitian ini menggunakan metode Regresi Linier Berganda. Adapun sampel dalam penelitian ini menggunakan teknik total sampling dimana semua anggota populasi digunakan sebagai sampel yang berjumlah 86 karyawan lapangan. Instrumen penelitian yang digunakan adalah wawancara dan kuesioner. Hasil penelitian ini adalah variabel kompensasi finansial berpengaruh positif terhadap motivasi kerja, Hal ini dilihat dari $t_{\text {hitung }}(3,203)$ lebih besar dari $t_{\text {tabel }}(1,66)$ dengan tingkat signifikan $(0,002<0,05)$. Variabel kompensasi non finansial berpengaruh positif terhadap motivasi kerja, hal ini dilihat dari $t_{\text {hitung }}(2,781)$ lebih besar dari $t_{\text {tabel }}(1,66)$ dengan tingkat signifikan $(0,007<0,05)$. Terdapat pengaruh secara simultan antara variabel kompensasi finansial dan kompensasi non finansial terhadap motivasi kerja, hal ini dilihat dari $F_{\text {hitung }}(13,451)$ lebih besar dari $\mathrm{F}_{\text {tabel }}(3,11)$ dengan tingkat signifikan $(0,000<0,05)$. Variabel kompensasi finansial berpengaruh positif terhadap kinerja karyawan, hal ini dilihat dari $t_{\text {hitung }}(2,917)$ lebih besar dari $t_{\text {tabel }}(1,66)$ dengan tingkat signifikan $(0,005<0,05)$. Variabel kompensasi non finansial berpengaruh positif terhadap kinerja karyawan, hal ini dilihat dari $t_{\text {hitung }}(2,311)$ lebih besar dari $t_{\text {tabel }}(1,66)$ dengan tingkat signifikan $(0,023<0,05)$. Terdapat pengaruh secara simultan
\end{abstract}


antara variabel kompensasi finansial dan kompensasi non finansial terhadap kinerja karyawan, hal ini dilihat dari $F_{\text {hitung }}(10,312)$ lebih besar dari $F_{\text {tabel }}(3,11)$ dengan tingkat signifikan $(0,000$ $<0,05)$.

Kata Kunci : Kompensasi Finansial, Kompensasi Non Finansial, Motivasi dan Kinerja 
Novi Indriani \& Adhitomo W, Pengaruh Kompensasi Finansial dan non Finansial...

\section{PENDAHULUAN}

Kompensasi menurut Laminingrum (2016) adalah segala sesuatu yang diterima karyawan sebagai balas jasa atas kerja yang telah dilakukan. Kompensasi merupakan faktor yang dapat mempengaruhi semangat dan kinerja karyawan, dimana pemberian kompensasi sangat penting bagi karyawan yang diharapkan mampu memberikan kesejahteraan hidup bagi karyawan tersebut sehingga dapat memotivasi karyawan agar bekerja lebih baik lagi yang akan berdampak pada peningkatan kinerja karyawan.

Menurut Lenni (2014), pada umumnya pemberian kompensasi yang diberikan oleh perusahaan dapat dibedakan dengan 2 macam yaitu finansial maupun non finansial. Menurut Afrida (2014), motivasi adalah suatu keadaan psikologis tertentu dalam diri seseorang yang muncul oleh karena adanya dorongan untuk memenuhi kebutuhan. Kinerja merupakan suatu hasil kerja yang dihasilkan karyawan. Menurut Afrida (2014), memberikan pengertian bahwa kinerja adalah hasil kerja secara kualitas dan kuantitas yang dicapai oleh seorang pegawai dalam melaksanakan tugasnya sesuai dengan tanggung jawab yang diberikan kepadanya. Dalam pemberian kompensasi sangat penting untuk benar-benar mengetahui apa yang dibutuhkan oleh karyawan, hal ini penting agar pemberian kompensasi dapat memberikan efek maksimal bagi peningkatkan motivasi kerja dan kinerja karyawan. Kompensasi dibutuhkan dalam sebuah organisasi tak terkecuali pada PT. United Sindo Perkasa, yaitu perusahaan dalam industri pembuatan dan perbaikan kapal. Beralamatkan di Jl Raya Pelabuhan Lama, Kabil, Batam. Adapun dua jenis kompensasi yang diberikan kepada karyawan terbagi dua, yaitu kompensasi finansial berupa gaji bulanan, THR, uang kerajinan, jaminan kesehatan, jaminan kecelakaan kerja, cuti tahunan, cuti sakit, cuti melahirkan (wanita) dan pembayaran over time dan kompensasi non finansial berupa training kerja, promosi jabatan, penghargaan prestasi kerja, lingkungan kerja yang bersih, alat kerja yang lengkap dan kerja sesuai SOP.

Masalah mendasar yang sering dihadapi perusahaan adalah bagaimana mengelola sumber daya manusia untuk melakukan tugas dengan sebaik-baiknya dalam rangka mencapai tujuan yang telah ditetapkan perusahaan. Ketika kinerja karyawan telah tercapai maka perusahaan dapat mengukur sejauh mana peningkatan kinerja yang telah dicapai. Setiap tahun perusahaan menyebarkan performance appraisal form kepada setiap supervisor untuk mengehui peningkatan prestasi kerja karyawan lapangan setiap tahunnya. Salah satu cara untuk memotivasi dan meningkatkan kinerja karyawan adalah dengan cara menetapkan metode kompensasi yang adil dan layak kepada karyawan tersebut atas prestasi kerja yang mereka capai. Ketika proses motivasi yang dilakukan oleh perusahaan kepada karyawan dalam bentuk pemberian kompensasi berjalan dengan lancar dan sesuai dengen perencanaannya maka tahapan selanjutnya yang diharapkan akan terjadi peningkatan kinerja karyawan lapangan.

Berdasarkan uraian-uraian yang telah dikemukakan di atas bahwa kompensasi tersebut sangat penting. Hal inilah yang mendorong peneliti tertarik untuk mengadakan penelitian dengan judul "Pengaruh Kompensasi Finansial dan Non Finansial Terhadap Motivasi Kerja dan Kinerja KaryawanBagian Lapangan Pada PT United Sindo Perkasa ".

\section{Rumusan Masalah}

Berdasarkan latar belakang penelitian yang telah dijelaskan diatas maka, dirumuskan masaalah sebagai berikut :
1. Apakah kompensasi finansial berpengaruh terhadap motivasi kerja karyawan bagian lapangan pada PT United Sindo Perkasa?

2. Apakah kompensasi non finansial berpengaruh terhadap motivasi kerja 
karyawan bagian lapangan pada PT United Sindo Perkasa?

3. Apakah kompensasi finansial dan non finansial secara simultan berpengaruh terhadap motivasi kerja karyawan bagian lapangan pada PT United Sindo Perkasa?

4. Apakah kompensasi finansial berpengaruh terhadap kinerja karyawan bagian lapangan pada PT United Sindo Perkasa?

5. Apakah kompensasi non finansial berpengaruh terhadap kinerja karyawan bagian lapangan pada PT United Sindo Perkasa?

6. Apakah kompensasi finansial dan non finansial secara simultan berpengaruh terhadap kinerja karyawan bagian lapangan pada PT United Sindo Perkasa?

\section{Tujuan Penelitian}

1. Untuk mengetahui pengaruh kompensasi finansial terhadap motivasi kerja karyawan bagian lapangan pada PT United Sindo Perkasa

2. Untuk mengetahui pengaruh kompensasi non finansial terhadap motivasi kerja karyawan bagian lapangan pada PT United Sindo Perkasa

3. Untuk mengetahui pengaruh secara simultan dari kompensasi finansial dan non finansial terhadap motivasi kerja karyawan bagian lapangan pada PT United Sindo Perkasa

4. Untuk mengetahui pengaruh kompensasi finansial terhadap kinerja karyawan bagian lapangan pada PT United Sindo Perkasa

5. Untuk mengetahui pengaruh kompensasi non finansial terhadap kinerja karyawan bagian lapangan pada PT United Sindo Perkasa

6. Untuk mengetahui pengaruh secara simultan dari kompensasi finansial dan non finansial terhadap kinerja karyawan bagian lapangan pada PT United Sindo Perkasa

\section{Manfaat Penelitian}

Hasil dari penelitian ini diharapkan dapat dijadikan masukan untuk mengetahui sejauh mana dari pelaksanaan program kompensasi dapat meningkatkan motivasi dan kinerja karyawan dalam menentukan, mengarahkan dan menciptakan maksimalisasi karyawan yang berada di dalam perusahaan. Serta hasil penelitian ini bermanfaat bagi upaya peningkatan mutu dan kualitas karyawan khususnya yang berkaitan dengan peningkatan prestasi kerja karyawan.

\section{KAJIAN PUSTAKA}

\section{Kompensasi Finansial}

Menurut Irawan (2014) adalah bentuk kompensasi yang dibayarkan kepada karyawan dalam bentuk uang atau jasa yang mereka sumbangkan pada perusahaan.

Kompensasi finansial dibagi menjadi dua kelompok, yaitu :

1.Kompensasi Finansial Langsung
a. Gaji
b. Bonus
c. Insentif

2.Kompensasi Finansial Langsung
a. Program asuransi
b. Tunjangan karyawan
c. Pembayaran untuk waktu tidak bekerja

\section{Kompensasi Non Finansial}

Menurut Suseno (2014), adalah kompensasi yang diberikan perusahaan selain kompensasi finansial. Kompensasi non finansial yang dikemukakan oleh Pratama (2015), membagi kompensasi non finansial menjadi dua bentuk yaitu :

1. Imbalan Karier
a. Rasa aman
b. Pengembangan diri
c. Peluang kenaikan penghasilan
d. Fleksibilitas karier

2. Imbalan Sosial
a. Kenyamanan tugas
b. Pujian dan pengakuan
c. Hubungan dengan rekan kerja
d. Simbol status 
Novi Indriani \& Adhitomo W, Pengaruh Kompensasi Finansial dan non Finansial...

\section{Motivasi Kerja}

Menurut Laminingrum (2016), mengatakan bahwa motivasi merupakan kemauan untuk mengeluarkan upaya yang tinggi untuk mencapai tujuan organisasi, yang dikondisikan oleh kemampuan upaya itu dalam memenuhi beberapa kebutuhan individual. Kemudian dari faktor kebutuhan tersebut, dijadikan sebagai indikatorindikator untuk mengetahui tingkat motivasi kerja karyawan, yaitu:

1. Kebutuhan fisik
a. Pemberian gaji
b. Uang makan
c. Uang transpotasi

2. Kebutuhan akan rasa aman
a. Jaminan sosial tenaga kerja
b. Dana pensiun
c. Tunjangan kesehatan Asuransi Kecelakaan
d. Perlangkapan keselamata kerja

3. Kebutuhan sosial/kasih sayang
a. Interaksi
b. Kebutuhan Sosial

4. Kebutuhan akan penghargaan
a. Kebutuhan akan kekuatan pencapaian, kecukupan dan kepercayaan.
b. Kebutuhan akan reputasi atau prestise

5. Kebutuhan perwujudan diri
a. Kecakapan
b. Kemampuan
c. Keterampilan

\section{Kinerja Karyawan}

Menurut Leonardo (2015), kinerja adalah kuantitas dan kualitas hasil kerja individu atau sekelompok di dalam perusahaan dalam melaksanakan tugas pokok dan fungsi yang berpedoman pada norma, standar operasional prosedur, kriteria dan ukuran yang telah ditetapkan atau yang berlaku dalam perusahaan. Terdapat tiga jenis kriteria-kriteria dalam penilaian prestasi kerja, Yaitu :
1. Sifat
a. Kemampuan
b. Loyalitas
c. Kejujuran
d. Kreatifitas
e. Kemampuan memimpin

2. Perilaku
a. Melaksanakan tugas
b. Mengikuti instruksi
c. Melaporkan permasalahan
d. Memelihara administrasi
e. Mengikuti aturan-aturan
f. Mengajukan usul

3. Hasil
a. Hasil yang di capai sesuai dengan perencanaan
b. Kualitas pekerjaan
c. Pekerjaan yang tersisa

\section{Kerangka Penelitian}

Kerangka pemikiran dibuat guna mempermudah pemahaman mengenai penelitian yang akan dilakukan. Adapun kerangka penelitian pada penelitian ini dijelaskan dibawah ini.

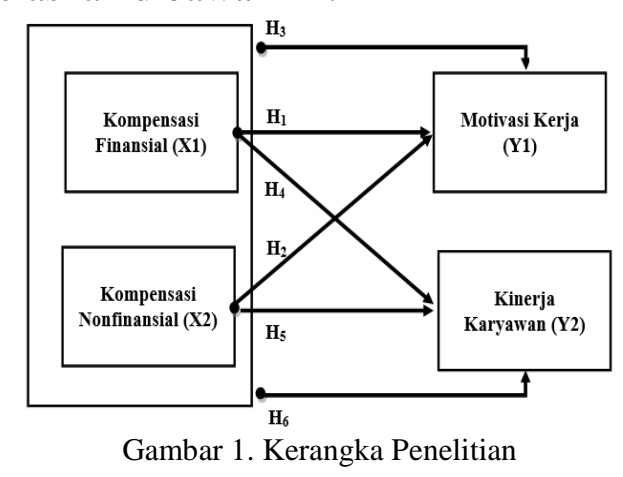

\section{METODE PENELITIAN \\ Desain/Jenis Penelitian}

Jenis penelitian yang ditetapkan dalam penelitian ini adalah penelitian penjelasan (Explanatory Research), dengan pendekatan kuantitatif. Singarimbun (dalam Irawan, 2014), menyatakan bahwa Penelitian penjelasan merupakan penelitian yang menyoroti hubungan-hubungan antara variabel-variabel penelitian dengan menguji hipotesis yang telah dirumuskan sebelumnya. 


\section{Objek dan Ruang Lingkup Penelitian}

Ruang lingkup dari penelitian ini adalah mencakup instansi penelitian yaitu objek seluruh karyawan lapangan PT. United Sindo Perkasa.

\section{Operasionalisasi Variabel}

Variabel penelitian adalah segala sesuatu yang berbentuk apa saja yang ditetapkan oleh peneliti untuk dipelajari sehingga diperoleh informasi tentang hal tersebut, kemudian ditarik kesimpulannya. Berdasarkan tujuan yang telah ditetapkan yaitu untuk mengetahui pengaruh kompensasi finansial dan kompensasi non finansial terhadap motivasi kerja dan kinerja karyawan di PT United Sindo Perkasa, dengan indikator yaitu:

1.Variabel bebas merupakan variabel yang mempengaruhi atau yang menjadi sebab perubahannya atau timbulnya variabel terikat. Dalam penelitian ini variabel bebas adalah kompensasi finansial $\left(\mathrm{X}_{1}\right)$ dan kompensasi non finansial $\left(\mathrm{X}_{2}\right)$. Adapun yang menjadi indikator kompensasi finansial yaitu kompensasi langsung dan kompensasi tidak langsung sedangkan kompensasi non finansial yaitu hukuman imbalan karier dan imbalan sosial.

2.Variabel terikat dalam penelitian ini yaiu motivasi kerja $\left(\mathrm{Y}_{1}\right)$ dankinerja karyawan sebagai $\left(\mathrm{Y}_{2}\right)$. Adapun yang menjadi indikator motivasi kerja yaitukebutuhan fisik, kebutuhan akan rasa aman, kebutuhan sosial/kasih sayang, kebutuhan penghargaan dan kebutuhan perwujudan diri sedangkan kinerja karyawan dengan indikator sifat, perilaku dan hasil.

\section{Populasi dan Sampel Populasi}

Populasi yang digunakan dalam penelitian ini adalah seluruh karyawan lapangan PT United Sindo Perkasa. Populasi dalam penelitian ini berjumlah 86 karyawan lapangan.

\section{Sampel}

Sampel adalah sebagian dari populasi tersebut. Dalam penelitian ini menggunakan teknik Total Sampling, Total Sampling adalah teknik penentuan sampel bila semua anggota populasi digunakan sebagai sampel. Sehingga total sampel yang digunakan adalah sebanyak 86 karyawan lapangan.

\section{Jenis dan Sumber Data}

Adapun jenis data dan sumber data yang digunakan dalam penelitian ini berupa:

1.Data Primer

Menurut Algifari (2015), data primer merupakan data yang diperoleh langsung dari dari obyek yang akan diteliti, baik langsung datang ke obyek, maupun melalui angket (kuesioner). Dalam penelitian ini peneliti memperoleh data dari karyawan PT. United Sindo Perkasa dengan menyebarkan kuesioner dan wawancara.

\section{Data Sekunder}

Menurut Algifari (2015), data sekunder adalah data yang diperoleh dari terbitan/laporan suatu lembaga. Data sekunder dalam penelitian ini berupa struktur organisasi perusahaan, dan dokumen lainnya yang mendukung penelitian ini.

\section{Teknik Pengumpulan Data}

Adapun teknik pengumpulan data yang dilakukan dalam penelitian ini adalah :

1.Wawancara

Dalam penelitian ini peneliti mewawancarai 1 karyawan kantor dengan jabatan Senior HR Executive dan 1 karyawan lapangan dengan jabatan foreman di PT United Sindo Perkasa.

\section{Kuesioner}

Kuesioner adalah teknik di mana mencari dan mengumpulkan data dengan cara memberikan selebaran kuesioner atau berupa pertanyaan-pertanyaan yang mana 
Novi Indriani \& Adhitomo W, Pengaruh Kompensasi Finansial dan non Finansial...

di dalamnya terdapat unsur pendapat dari karyawan PT. United Sindo Perkasa yang hasilnya dapat menyempurnakan penelitian ini. Pengukuran data yang dilakukan dalam penelitian ini adalah skala ordinal dengan urutan sebagai berikut:

1.Untuk jawaban SS, yaitu sangat setuju diberikan skor : 4

2.Untuk jawaban $\mathrm{S}$, yaitu setuju diberi skor $: 3$

3.Untuk jawabanTS, yaitu tidak setuju diberi skor : 2

4.Untuk jawaban STS, yaitu sangat tidak setuju diberi skor : 1

\section{HASIL DAN PEMBAHASAN}

\section{Validitas dan Reliabilita}

\section{Uji Validitas}

Menurut Ghozali (dalam Gunawan 2016), uji validitas digunakan untuk mengukur sah atau valid tidaknya suatu kuesioner. Suatu kuesioner dinyatakan valid ketika pertanyaan pada kuesioner mampu untuk mengungkapkan sesuatu yang akan diukur oleh kuesioner tersebut. Dalam uji validitas digunakan rumus:

$$
\mathrm{r}=\frac{n \sum X Y-\left(\sum X\right)\left(\sum Y\right)}{\sqrt{n \sum X^{2}-\left(\sum X^{2}\right)} \sqrt{n \sum Y^{2}-\left(\sum Y^{2}\right)}}
$$

Dimana :

$\mathrm{r} \quad=$ koefisien korelasi

$\mathrm{X}=$ skor tiap pertanyaan/ item

$\mathrm{Y}=$ skor total

$\mathrm{n}=$ jumlah responden

\section{Tabel 1. Hasil Uji Validitas}

\begin{tabular}{|c|c|c|c|}
\hline \multicolumn{5}{|l|}{ Kompensasi Finansial $\left(\mathbf{X}_{\mathbf{1}}\right)$} \\
\hline Item & r hitung & r tabel & Keterangan \\
\hline $\mathbf{X}_{\mathbf{1 . 1}}$ & 0,607 & 0,2120 & Valid \\
\hline $\mathbf{X}_{\mathbf{1 . 2}}$ & 0,806 & 0,2120 & Valid \\
\hline $\mathbf{X}_{\mathbf{1 . 3}}$ & 0,589 & 0,2120 & Valid \\
\hline $\mathbf{X}_{\mathbf{1 . 4}}$ & 0,792 & 0,2120 & Valid \\
\hline
\end{tabular}

\begin{tabular}{|c|c|c|c|}
\hline $\mathbf{X}_{1.5}$ & 0,536 & 0,2120 & Valid \\
\hline $\mathrm{X}_{1.6}$ & 0,663 & 0,2120 & Valid \\
\hline \multicolumn{4}{|c|}{ Kompensasi Non Finansial $\left(\mathbf{X}_{2}\right)$} \\
\hline $\mathbf{X}_{2.1}$ & 0,785 & 0,2120 & Valid \\
\hline $\mathbf{X}_{2.2}$ & 0,823 & 0,2120 & Valid \\
\hline $\mathbf{X}_{2.3}$ & 0,835 & 0,2120 & Valid \\
\hline $\mathbf{X}_{2.4}$ & 0,790 & 0,2120 & Valid \\
\hline $\mathbf{X}_{2.5}$ & 0,742 & 0,2120 & Valid \\
\hline $\mathbf{X}_{2.6}$ & 0,713 & 0,2120 & Valid \\
\hline $\mathbf{X}_{2.7}$ & 0,755 & 0,2120 & Valid \\
\hline \multicolumn{4}{|c|}{ Motivasi Kerja $\left(\mathbf{Y}_{1}\right)$} \\
\hline $\mathbf{Y}_{1.1}$ & 0,547 & 0,2120 & Valid \\
\hline $\mathbf{Y}_{1.2}$ & 0,735 & 0,2120 & Valid \\
\hline $\mathbf{Y}_{1.3}$ & 0,775 & 0,2120 & Valid \\
\hline $\mathbf{Y}_{1.4}$ & 0,844 & 0,2120 & Valid \\
\hline $\mathbf{Y}_{1.5}$ & 0,842 & 0,2120 & Valid \\
\hline $\mathbf{Y}_{1.6}$ & 0,825 & 0,2120 & Valid \\
\hline $\mathbf{Y}_{1.7}$ & 0,827 & 0,2120 & Valid \\
\hline $\mathbf{Y}_{1.8}$ & 0,863 & 0,2120 & Valid \\
\hline $\mathbf{Y}_{1.9}$ & 0,854 & 0,2120 & Valid \\
\hline $\mathbf{Y}_{1.10}$ & 0,729 & 0,2120 & Valid \\
\hline $\mathbf{Y}_{1.11}$ & 0,756 & 0,2120 & Valid \\
\hline $\mathbf{Y}_{1.12}$ & 0,719 & 0,2120 & Valid \\
\hline $\mathbf{Y}_{1.13}$ & 0,642 & 0,2120 & Valid \\
\hline $\mathbf{Y}_{1.14}$ & 0,613 & 0,2120 & Valid \\
\hline \multicolumn{4}{|c|}{ Kinerja Karyawan $\left(\mathbf{Y}_{2}\right)$} \\
\hline $\mathbf{Y}_{2.1}$ & 0,304 & 0,2120 & Valid \\
\hline $\mathbf{Y}_{2.2}$ & 0,584 & 0,2120 & Valid \\
\hline $\mathbf{Y}_{2.3}$ & 0,447 & 0,2120 & Valid \\
\hline $\mathbf{Y}_{2.4}$ & 0,388 & 0,2120 & Valid \\
\hline $\mathbf{Y}_{2.5}$ & 0,410 & 0,2120 & Valid \\
\hline $\mathbf{Y}_{2.6}$ & 0,319 & 0,2120 & Valid \\
\hline $\mathbf{Y}_{2.7}$ & 0,516 & 0,2120 & Valid \\
\hline $\mathbf{Y}_{2.8}$ & 0,461 & 0,2120 & Valid \\
\hline $\mathbf{Y}_{2.9}$ & 0,388 & 0,2120 & Valid \\
\hline $\mathbf{Y}_{2.10}$ & 0,306 & 0,2120 & Valid \\
\hline $\mathbf{Y}_{2.11}$ & 0,568 & 0,2120 & Valid \\
\hline
\end{tabular}


Journal of Business Administration Vol 3, No.1, Maret 2019, hlm, 64-78

\begin{tabular}{|c|c|c|c|}
\hline $\mathbf{Y}_{\mathbf{2 . 1 2}}$ & 0,483 & 0,2120 & Valid \\
\hline $\mathbf{Y}_{\mathbf{2 . 1 3}}$ & 0,448 & 0,2120 & Valid \\
\hline $\mathbf{Y}_{\mathbf{2 . 1 4}}$ & 0,381 & 0,2120 & Valid \\
\hline
\end{tabular}

(Sumber: Pengolahan Data, 2018)

Terlihat dari semua item skor dari setiap instrument uji validitas pada Tabel 2. adalah $r_{\text {hitung }}>r_{\text {tabel }}$ dengan nilai $r_{\text {tabel }}$ (0.2120) yang berarti bahwa setiap instrument dari item pertanyaan dinyatakan valid. Nilai $r_{\text {tabel }}(0.2120)$ dicari pada signifikansi $5 \%$ dengan persamaan $\mathrm{Df}=\mathrm{n}-$ $\mathrm{k}=86-2=84$.

\section{Uji Reliabilitas}

Menurut Ghozali (dalam Gunawan, 2016), uji reliabilitas adalah alat untuk mengukur suatu kuesioner yang merupakan indikator dari variabel atau konstruk. Dalam penelitian ini pengukuran reliabilitas kuesioner melalui uji statistik Cronbach Alpha $(\alpha)$ dengan program SPSS for windows. Suatu konstruk atau variabel dapat dikatakan reliabel jika memberikan nilai Cronbach Alpha > 0,60 pada hasil pengujian.

$$
r_{11}=\left[\frac{k}{(k-1)}\right]\left[1-\frac{\Sigma \sigma_{b}^{2}}{\sigma_{t}^{2}}\right]
$$

Keterangan :

$\mathrm{r}_{11}$ : Reliabilitas yang dicari

n : Jumlah item pertanyaan yang di uji

$\sum \sigma_{\mathrm{t}}^{2}:$ Jumlah varians skor tiap-tiap item $\sigma_{\mathrm{t}}^{2}:$ Varians total

Tabel 2. Hasil Uji Reliabilitas

\begin{tabular}{|c|c|c|c|}
\hline Item & $\begin{array}{l}\text { Cronbach's Alpha } \\
\text { if item Deleted }\end{array}$ & $\begin{array}{l}\text { Cronbach's } \\
\text { Alpha }\end{array}$ & Keterangan \\
\hline \multicolumn{4}{|c|}{ Kompensasi Finansial $\left(\mathbf{X}_{1}\right)$} \\
\hline $\mathbf{X}_{1.1}$ & 0,709 & \multirow{3}{*}{$\begin{array}{r}0,769 \\
>0,6\end{array}$} & Reliabel \\
\hline $\mathbf{X}_{1.2}$ & 0,686 & & Reliabel \\
\hline $\mathbf{X}_{1.3}$ & 0,771 & & Reliabel \\
\hline
\end{tabular}

\begin{tabular}{|c|c|c|c|}
\hline Item & $\begin{array}{l}\text { Cronbach's Alpha } \\
\text { if item Deleted }\end{array}$ & $\begin{array}{l}\text { Cronbach's } \\
\text { Alpha }\end{array}$ & Keterangan \\
\hline $\mathbf{X}_{1.4}$ & 0,696 & & Reliabel \\
\hline $\mathbf{X}_{1.5}$ & 0,788 & & Reliabel \\
\hline $\mathbf{X}_{1.6}$ & 0,738 & & Reliabel \\
\hline \multicolumn{4}{|c|}{ Kompensasi Non Finansial $\left(\mathbf{X}_{2}\right)$} \\
\hline $\mathbf{X}_{2,1}$ & 0,880 & \multirow{7}{*}{$\begin{array}{l}0,894 \\
>0,6\end{array}$} & Reliabel \\
\hline $\mathbf{X}_{2.2}$ & 0,873 & & Reliabel \\
\hline $\mathbf{X}_{2.3}$ & 0,870 & & Reliabel \\
\hline $\mathbf{X}_{2.4}$ & 0,873 & & Reliabel \\
\hline$\overline{\mathbf{X}_{2.5}}$ & 0,886 & & Reliabel \\
\hline $\mathbf{X}_{2.6}$ & 0,893 & & Reliabel \\
\hline $\mathbf{X}_{2.7}$ & 0,870 & & Reliabel \\
\hline \multicolumn{4}{|c|}{ Motivasi Kerja $\left(\mathbf{Y}_{1}\right)$} \\
\hline$Y_{1.1}$ & 0,944 & \multirow{14}{*}{$\begin{array}{l}0,942 \\
>0,6\end{array}$} & Reliabel \\
\hline $\mathbf{Y}_{1.2}$ & 0,939 & & Reliabel \\
\hline $\mathbf{Y}_{1.3}$ & 0,937 & & Reliabel \\
\hline $\mathbf{Y}_{1.4}$ & 0,935 & & Reliabel \\
\hline $\mathbf{Y}_{1.5}$ & 0,935 & & Reliabel \\
\hline $\mathbf{Y}_{1.6}$ & 0,936 & & Reliabel \\
\hline $\mathbf{Y}_{1.7}$ & 0,936 & & Reliabel \\
\hline $\mathbf{Y}_{1.8}$ & 0,934 & & Reliabel \\
\hline $\mathbf{Y}_{1.9}$ & 0,935 & & Reliabel \\
\hline $\mathbf{Y}_{1.10}$ & 0,939 & & Reliabel \\
\hline $\mathbf{Y}_{1.11}$ & 0,938 & & Reliabel \\
\hline $\mathbf{Y}_{1.12}$ & 0,939 & & Reliabel \\
\hline $\mathbf{Y}_{1.13}$ & 0,942 & & Reliabel \\
\hline $\mathbf{Y}_{1.14}$ & 0,942 & & Reliabel \\
\hline \multicolumn{4}{|c|}{ Kinerja Karyawan $\left(\mathbf{Y}_{2}\right)$} \\
\hline $\mathbf{Y}_{2.1}$ & 0,656 & \multirow{8}{*}{$\begin{array}{l}0,660 \\
>0,6\end{array}$} & Reliabel \\
\hline $\mathbf{Y}_{2.2}$ & 0,617 & & Reliabel \\
\hline $\mathbf{Y}_{2.3}$ & 0,638 & & Reliabel \\
\hline $\mathbf{Y}_{2.4}$ & 0,650 & & Reliabel \\
\hline $\mathbf{Y}_{2.5}$ & 0,648 & & Reliabel \\
\hline $\mathbf{Y}_{2.6}$ & 0,660 & & Reliabel \\
\hline $\mathbf{Y}_{2.7}$ & 0,630 & & Reliabel \\
\hline $\mathbf{Y}_{2.8}$ & 0,637 & & Reliabel \\
\hline
\end{tabular}


Novi Indriani \& Adhitomo W, Pengaruh Kompensasi Finansial dan non Finansial...

\begin{tabular}{|c|c|c|c|}
\hline Item & $\begin{array}{l}\text { Cronbach's Alpha } \\
\text { if item Deleted }\end{array}$ & $\begin{array}{l}\text { Cronbach's } \\
\text { Alpha }\end{array}$ & Keterangan \\
\hline $\mathbf{Y}_{2.9}$ & 0,650 & & Reliabel \\
\hline $\mathbf{Y}_{2.10}$ & 0,664 & & Reliabel \\
\hline $\mathbf{Y}_{\mathbf{2 . 1 1}}$ & 0,620 & & Reliabel \\
\hline $\mathbf{Y}_{2.12}$ & 0,636 & & Reliabel \\
\hline $\mathbf{Y}_{2.13}$ & 0,639 & & Reliabel \\
\hline $\mathbf{Y}_{2.14}$ & 0,648 & & Reliabel \\
\hline
\end{tabular}

(Sumber : Pengolahan Data, 2018)

Berdasarkan Tabel 2. diketahui bahwa keempat variabel dalam penelitian ini masing-masing memiliki nilai Cronbach's Alpha lebih besar dari 0.6 sehingga dapat disimpulkan bahwa alat ukur yang digunakan tersebut reliable, konsisten dan relevan sehingga layak untuk diproses lebih lanjut.

\section{Metode Analisis Data Statistik Deskriptif}

Menurut Sugiono (2014), statistik deskriptif adalah statistik yang digunakanan untuk menganalisis data dengan cara mendeskripsikan atau menggambarkan data yang telah terkumpul sebagaimana adanya tanpa bermaksud membuat kesimpulan yang berlaku untuk umum atau generalisasi.

Hasil analisis responden berdasarkan jenis kelamin, status, umur, pendidikan, masa bekerja dapat dilihat pada Tabel 3 berikut ini:

Tabel 3. Statistik Deskriptif berdasarkan jenis kelamin, usia, pendidikan, jabatan, masa kerja dan gaji

\begin{tabular}{|l|l|}
\hline Karakteristik Responden & \multicolumn{1}{|c|}{ Keterangan } \\
\hline Jenis Kelamin & \\
\hline Laki-laki & 86 responden $(100 \%)$ \\
\hline Perempuan & 0 responden $(0 \%)$ \\
\hline Usia & \\
\hline$<20$ tahun & 0 responden $(0 \%)$ \\
\hline $21-30$ tahun & 14 responden $(16,3 \%)$ \\
\hline
\end{tabular}

\begin{tabular}{|c|c|}
\hline $31-40$ tahun & 49 responden $(57 \%)$ \\
\hline$>40$ tahun & 23 responden $(26,7 \%)$ \\
\hline \multicolumn{2}{|l|}{ Pendidikan } \\
\hline SMP & 9 responden $(10,5 \%)$ \\
\hline SMA/SMK & 72 responden $(83.7 \%)$ \\
\hline Diploma & 1 responden $(1,2 \%)$ \\
\hline S1 (D4) & 4 responden $(4,7 \%)$ \\
\hline \multicolumn{2}{|l|}{ Jabatan } \\
\hline Blaster/Painter & 4 responden $(4,7 \%)$ \\
\hline Electrician & 5 responden $(5,8 \%)$ \\
\hline Engineer & 2 responden $(2,3 \%)$ \\
\hline Fitter & 14 responden $(16,3 \%)$ \\
\hline Foreman & 19 responden $(22,1 \%)$ \\
\hline Helper & 9 responden $(10,5 \%)$ \\
\hline$H O D$ & 1 responden $(1,2 \%)$ \\
\hline Mechanic & 5 responden $(5,8 \%)$ \\
\hline Operator Crane & 6 responden $(7 \%)$ \\
\hline Rigger & 1 responden $(1,2 \%)$ \\
\hline Safety & 4 responden $(4,7 \%)$ \\
\hline Scaffolding & 2 responden $(2,3 \%)$ \\
\hline Storeman & 3 responden $(3,5 \%)$ \\
\hline Welder & 11 responden $(12,8 \%)$ \\
\hline \multicolumn{2}{|l|}{ Masa Kerja } \\
\hline$<1$ tahun & 1 responden $(1,2 \%)$ \\
\hline $1-5$ tahun & 25 responden $(29,1 \%)$ \\
\hline 6-10 tahun & 54 responden $(62,8 \%)$ \\
\hline$>10$ tahun & 6 responden $(7 \%)$ \\
\hline \multicolumn{2}{|l|}{ Gaji } \\
\hline$<3 \mathrm{jt}$ & 0 responden $(0 \%)$ \\
\hline $3,1-4 \mathrm{jt}$ & 72 responden $(83,7 \%)$ \\
\hline $4,1-5 \mathrm{jt}$ & 11 responden $(12,8 \%)$ \\
\hline$>5 \mathrm{jt}$ & 3 responden $(3,5 \%)$ \\
\hline
\end{tabular}

(Sumber : Hasil Pengolahan Data, 2018)

\section{Statistik Inferensial}

Menurut Sugiono (2014), statistik inferensial adalah teknik statistik yang digunakan untuk menganalisis data sampel dan hasilnya diberlakukan untuk populasi. Metode analisis yang menggunakan data 
berupa angka dan analisis dengan cara membandingkan melalui perhitungan dan mengaplikasikannya dengan menggunakan rumus yang sesuai.

Pengelolaan analisis inferensial dilakukan dengan menggunakan program SPSS.

\section{Uji Asumsi Klasik}

\section{Uji Normalitas}

Uji Normalitas bertujuan untuk menguji model regresi apakah variabel dependen dalam penelitian ini mempunyai distribusi normal atau tidak normal. Menurut Ghozali (2011), hasil pengujian normalitas data ditunjukkan dengan nilai asymp sig (2 tailed), apabila nilai asymp sig > 0,05 maka dapat disimpulkan bahwa data berdistribusi normal.

Tabel 4. Hasil Uji Sampel K-S

One-Sample Kolmogorov-Smirnov Test

\begin{tabular}{l|r|r}
\hline & Motivasi_Kerja & $\begin{array}{c}\text { Kinerja_Karya } \\
\text { wan }\end{array}$ \\
\hline $\begin{array}{l}\text { Kolmogorov- } \\
\text { Smirnov Z }\end{array}$ & .767 & .886 \\
$\begin{array}{l}\text { Asymp. Sig. (2- } \\
\text { tailed) }\end{array}$ & .599 & .412 \\
\hline \multicolumn{2}{c}{ (Sumber : Hasil Pengolahan Data, 2018) }
\end{tabular}

Tabel diatas menunjukan KolmogorovSmirnov memiliki variabel dependen motivasi kerja tingkat signifikansi lebih besar dari 0,05 yaitu 0,599. Dan uji Kolmogorov-Smirnovmemiliki variabel dependen kinerja karyawan tingkat signifikansi lebih besar dari 0,05 yaitu 0,412 . Dengan demikian dapat disimpulkan bahwa model berdistribusi normal.

\section{Uji Multikolinieritas}

Model regresi yang baik adalah model yang bebas dari multikolinieritas. Uji multikolinieritas dapat dilihat dari besarnya VIF (Variance Inflation Factor) dan tolerance. Menurut Ghozali (2011), mengatakan suatu model regresi yang bebas dari multikolinieritas adalah mempunyai nilai VIF $<10$ dan angka tolerance $>10 \%$. Apabila nilai signifikansi variabel bebas $>0,05$, maka tidak terjadi heteroskedastisitas. Sebaliknya, jika nilai signifikansi variabel bebas $<0,05$, maka terjadi masalah heteroskedastisitas.

\begin{tabular}{|c|c|c|c|c|}
\hline \multirow{2}{*}{$\begin{array}{l}\text { Depe } \\
\text { nden } \\
(Y)\end{array}$} & \multirow{2}{*}{$\begin{array}{l}\text { Independ } \\
\text { en }(X)\end{array}$} & \multicolumn{2}{|c|}{$\begin{array}{c}\text { Colinearity } \\
\text { Statistics }\end{array}$} & \multirow{2}{*}{ Keterangan } \\
\hline & & $\begin{array}{l}\text { Toler } \\
\text { ance }\end{array}$ & VIF & \\
\hline \multirow{2}{*}{$\begin{array}{l}\text { Motiv } \\
\text { asi }\end{array}$} & $\begin{array}{l}\text { Kompensa } \\
\text { si } \\
\text { Finansial }\end{array}$ & 0,889 & $\begin{array}{c}1,12 \\
5\end{array}$ & $\begin{array}{c}\text { Tidak ada } \\
\text { Multikolinierit } \\
\text { as }\end{array}$ \\
\hline & $\begin{array}{l}\text { Kompensa } \\
\text { si Non } \\
\text { Finansial }\end{array}$ & 0,889 & $\begin{array}{c}1,12 \\
5\end{array}$ & $\begin{array}{c}\text { Tidak ada } \\
\text { Multikolinierit } \\
\text { as }\end{array}$ \\
\hline \multirow{2}{*}{$\begin{array}{l}\text { Kine } \\
\text { rja }\end{array}$} & $\begin{array}{l}\text { Kompensa } \\
\text { si } \\
\text { Finansial }\end{array}$ & 0,889 & $\begin{array}{c}1,12 \\
5\end{array}$ & $\begin{array}{c}\text { Tidak ada } \\
\text { Multikolinierit } \\
\text { as }\end{array}$ \\
\hline & $\begin{array}{l}\text { Kompensa } \\
\text { si Non } \\
\text { Finansial }\end{array}$ & 0,889 & $\begin{array}{c}1,12 \\
5\end{array}$ & $\begin{array}{c}\text { Tidak ada } \\
\text { Multikolinierit } \\
\text { as }\end{array}$ \\
\hline & Sumbre & & & Data, 2018) \\
\hline
\end{tabular}

Berdasarkan Tabel diatas diketahui bahwa hasil uji multikolinieritas menunjukkan kompensasi finansial dan kompensasi non finansial memiliki nilai tolerance sebesar 0.889. Hal ini menunjukkan tidak ada variabel independen yang memiliki nilai tolerance kurang dari 0,10 yang berarti tidak ada korelasi antar variabel independen. Hasil perhitungan nilai Variance Inflation Factor (VIF) juga menunjukkan hasil sebesar 1,125 untuk kompensasi finansial dan kompensasi non finansial. Jika nilai VIF yang dihasilkan diantara 1-10 maka tidak terjadi multikolinearitas (Ghozali (2011)). Dalam penelitian ini dimana tidak ada satu variabel independen yang memiliki nilai VIF lebih dari 10. Jadi dapat disimpulkan bahwa tidak ada multikolinieritas antar variabel independen dalam model regresi.

\section{Uji Heteroskedastisitas}

Uji heteroskedastisitas bertujuan untuk menguji apakah dalam model regresi ketidaksamaan variansi dari residual satu pengamatan ke pengamatan lain.Apabila 
Novi Indriani \& Adhitomo W, Pengaruh Kompensasi Finansial dan non Finansial...

nilai signifikansi variabel bebas $>0,05$, maka tidak terjadi heteroskedastisitas. Sebaliknya, jika nilai signifikansi variabel bebas <0,05, maka terjadi masalah heteroskedastisitas.

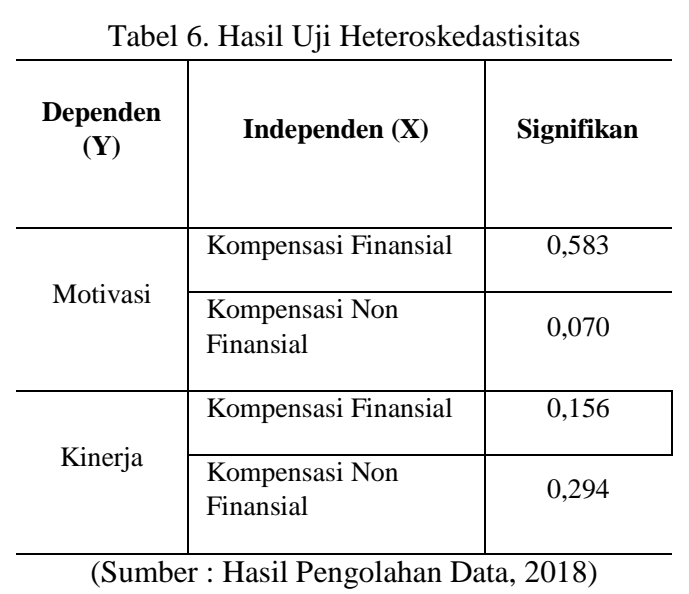

Berdasarkan Tabel diatas diketahui hasil ditampilkan bahwa variabel independen yaitu $\mathrm{X}_{1}$ (kompensasi finansial) dengan tingkat signfikan sebesar 0,583 dan $\mathrm{X}_{2}$ (kompensasi non finansial) dengan tingkat signifikan sebesar 0,070 serta variabel independen yaitu $\mathrm{X}_{1}$ (kompensasi finansial) dengan tingkat signfikan sebesar 0,156 dan $\mathrm{X}_{2}$ (kompensasi non finansial) dengan tingkat signifikan sebesar 0,294 maka variabel $>0,05$. Sehingga dapat disimpulkan bahwa model regresi tidak mengandung adanya heterokesdastisitas.

\section{Uji Autokorelasi}

Uji Autokorelasi dilakukan untuk menguji apakah model regerensi linier ada korelasi antara kesalahan pengganggu pada suatu periode dengan kesalahan pada periode sebelumnya yang biasanya terjadi karena menggunakan data time series. Jika terjadi korelasi, maka dinamakan ada masalah autokorelasi. Mendeteksi autokorelasi dengan menggunakan nilai Durbin Watson dibandingkan dengan Tabel Durbin Watson (dl dan du). Kriteria jika du $<\mathrm{d}$ hitung $<$ 4-du maka tidak terjadi autokorelasi (Sujarweni, 2015).

Tabel 7. Hasil Uji Autokorelasi

\begin{tabular}{c|c|c|c|c}
\multicolumn{5}{c}{ Tabel 7. Hasil Uji Autokorelasi } \\
\hline $\begin{array}{c}\text { Dependen } \\
(\mathbf{Y})\end{array}$ & Independen (X) & d & du & 4-du \\
\hline
\end{tabular}

\begin{tabular}{c|l|c|c|c}
\hline $\begin{array}{c}\text { Dependen } \\
(\mathbf{Y})\end{array}$ & Independen $(\mathbf{X})$ & $\mathbf{d}$ & $\mathbf{d u}$ & $\mathbf{4 - d u}$ \\
\hline \multirow{5}{*}{ Motivasi } & $\begin{array}{l}\text { Kompensasi } \\
\text { Finansial }\end{array}$ & \multirow{1}{*}{1,799} & 1,697 & 2,303 \\
\cline { 2 - 3 } & $\begin{array}{l}\text { Kompensasi Non } \\
\text { Finansial }\end{array}$ & & & \\
\hline \multirow{5}{*}{ Kinerja } & $\begin{array}{l}\text { Kompensasi } \\
\text { Finansial }\end{array}$ & $\begin{array}{l}\text { Kompensasi } \\
\text { Non } 1,707\end{array}$ & 1,697 & 2,303 \\
& $\begin{array}{l}\text { Non } \\
\text { Finansial }\end{array}$ & & \\
\hline
\end{tabular}

Berdasarkan Tabel diatas ditas diketahui bahwa Durbin-Watson 1,799 dan 1,707. Jika nilai $\mathrm{du}<\mathrm{dw}<4$-du maka tidak terjadi autokorelasi (Sujarweni, 2015). Pada tabel diatas dengan variabel dependen motivasi kerja terdapat $\mathrm{dw}=1,799$ dengan jumlah sampel $\mathrm{N}=86$ dan jumlah variabel independen $2(\mathrm{~K}=2)$ maka diperoleh nilai $\mathrm{du}=1,697$ (pada Tabel Durbin-Watson). Nilai $1,1697<1,799<2,303$ maka dapat disimpulkan tidak terjadi autokorelasi.

Sedangkan variabel dependen kinerja karyawan terdapat $\mathrm{dw}=1,707$ dengan jumlah sampel $\mathrm{N}=86$ dan jumlah variabel dependen $2(\mathrm{~K}=2)$ maka diperoleh nilai $\mathrm{du}=1,697$ (pada tabel Durbin Watson). Nilai $1,697<1,707<2,303$ maka dapat disimpulkan tidak terjadi autokorelasi.

\section{Analisis Regresi Linier Berganda}

Analisis regresi berganda digunakan dalam penelitian ini bertujuan untuk membuktikan hipotesis mengenai variabel kompensasi finansial dan kompensasi non finansial secara parsial maupun simultan terhadap motivasi kerja dan kinerja karyawan. Maka dalam penelitian ini menggunakan rumus regresi berganda, karena lebih dari satu variabel yang akan diteliti.

$$
Y^{\prime}=a+b_{1} X_{1}+b_{2} X_{2}+\ldots . .+b_{n} X_{n}
$$

Dimana:

$\mathrm{Y} \quad=$ Variabel dependen

$\mathrm{a} \quad=$ Konstanta

$\mathrm{X}_{1}=$ Variabel independen 
$\mathrm{X}_{2}=$ Variabel independen

$b_{1} b_{2}=$ Keofisien regresi variabel

Hasil pengolahan data dengan menggunakan program SPSS selengkapnya ada pada lampiran dan selanjutnya dijelaskan pada Tabel berikut ini:

Tabel 8. Hasil Analisis Regresi Linier Berganda

\begin{tabular}{|c|c|c|c|c|}
\hline $\begin{array}{c}\text { Dependen } \\
\text { (Y) }\end{array}$ & $\begin{array}{c}\text { Independen } \\
\text { (X) }\end{array}$ & B & $\mathbf{t}$ & Sig. \\
\hline \multirow{3}{*}{$\begin{array}{l}\text { Motivasi } \\
\text { Kerja }\end{array}$} & (Constant) & 21,355 & & \\
\hline & $\begin{array}{l}\text { Kompensasi } \\
\text { Finansial }\end{array}$ & 1,034 & 3,203 & 0,002 \\
\hline & $\begin{array}{l}\text { Kompensasi } \\
\text { Non Finansial }\end{array}$ & 0,607 & 2,781 & 0,007 \\
\hline \multirow{3}{*}{$\begin{array}{c}\text { Kinerja } \\
\text { Karyawan }\end{array}$} & (Constant) & 31,291 & & \\
\hline & $\begin{array}{l}\text { Kompensasi } \\
\text { Finansial }\end{array}$ & 0,633 & 2,917 & 0,005 \\
\hline & $\begin{array}{l}\text { Kompensasi } \\
\text { Non Finansial }\end{array}$ & 0,339 & 2,311 & 0,023 \\
\hline
\end{tabular}

$Y_{1}=21,355+1,034 X_{1}+0,607 X_{2}+e$

$Y_{2}=31,291+0,633 X_{1}+0,339 X_{2}+e$

Persamaan regresi pada Tabel diatas dapat dijelaskan sebagai berikut:

a.Konstanta dengan variabel dependen motivasi memiliki nilai sebesar 21,355 yang berarti bahwa jika variabel kompensasi finansial $\left(\mathrm{X}_{1}\right)$, kompensasi non finansial $\left(\mathrm{X}_{2}\right)$ bernilai 0 , maka variabel motivasi memiliki nilai sebesar 21,355 .

b.Konstanta dengan variabel dependen kinerja memiliki nilai sebesar 31,291 yang berarti bahwa jika variabel kompensasi finansial $\left(\mathrm{X}_{1}\right)$, kompensasi non finansial $\left(\mathrm{X}_{2}\right)$ bernilai 0 , maka variabel kiberja memiliki nilai sebesar 31,291

c.Koefisien regresi dengan variabel dependen motivasi memiliki nilai pada variabel kompensasi finansial 3,203 yang menunjukkan bahwa variabel ini berpengaruh positif dan signifikan.
d.Koefisien regresi dengan variabel dependen motivasi memiliki nilai pada variabel kompensasi non finansial 2,781 yang menunjukkan bahwa variabel ini berpengaruh positif dan signifikan.

e.Koefsien regresi dengan variabel dependen kinerja memiliki nilai pada variabel kompensasi finansial 2,917 yang menunjukkan bahwa variabel ini berpengaruh positif dan signifikan.

f. Koefisien regresi dengan variabel dependen motivasi memiliki nilai pada variabel kompensasi non finansial 2,311 yang menunjukkan bahwa variabel ini berpengaruh positif dan signifikan.

g.Uji t pada varaibel kompensasi finansial memiliki nilai $t_{\text {hitung }}(3,203)>t_{\text {tabel }}(1,66)$ yang berarti terdapat pengaruh secara parsial terhadap variabel motivasi. Uji $t$ pada varaibel kompensasi non finansial memiliki nilai $t_{\text {hitung }}(2,781)>t_{\text {tabel }}(1,66)$ yang berarti terdapat pengaruh secara parsial terhadap variabel motivasi. Uji $t$ pada varaibel kompensasi finansial memiliki nilai $t_{\text {hitung }}(2,917)>t_{\text {tabel }}(1,66)$ yang berarti terdapat pengaruh secara parsial terhadap variabel kinerja. Uji $t$ pada varaibel kompensasi non finansial memiliki nilai $t_{\text {hitung }}(2,311)>t_{\text {tabel }}(1,66)$ yang berarti terdapat pengaruh secara parsial terhadap variabel kinerja.

h.Hasil Uji diperoleh nilai $F_{\text {hitung }}(13,451)>$ $F_{\text {tabel }} \quad(3,11)$ yang berarti variabel kompensasi finansial dan kompensasi non finansial berpengaruh secara simultan terhadap motivasi kerja karyawan. Hasil Uji diperoleh nilai $F_{\text {hitung }}(10,312)>F_{\text {tabel }}$ $(3,11)$ yang berarti variabel kompensasi finansial dan kompensasi non finansial berpengaruh secara simultan terhadap motivasi karyawan.

i. Hasil Uji $R$ Square sebesar 0,245 dan 0,199 yang berarti variabel motivasi dan kinerja dipengaruhi sebesar $44,4 \%$ oleh variabel kompensasi finansial dan kompensasi non finansial sementara sisanya sebesar $55,6 \%$ dipengaruhi oleh variabel lain yang tidak diteliti dalam penelitian ini. 
Novi Indriani \& Adhitomo W, Pengaruh Kompensasi Finansial dan non Finansial...

\section{Koefisien Determinasi $\left(\mathbf{R}^{2}\right)$}

Koefisien Determinasi merupakan persentase pengaruh semua variabel bebas terhadap variabel terikat. Untuk mengetahui besarnya pengaruh kompensasi finansial dan kompensasi non finansial terhadap motivasi kerja dan kinerja karyawan lapangan, dapat di lihat pada Tabel 9 berikut ini :

Tabel 9. Hasil Uji Koefisien Determinasi

\begin{tabular}{l|c|c|c}
\hline \multicolumn{1}{c|}{$\begin{array}{c}\text { Dependen } \\
(\mathbf{Y})\end{array}$} & $\boldsymbol{R}$ & $\begin{array}{c}\boldsymbol{R} \\
\text { Square }\end{array}$ & $\begin{array}{c}\text { Adjusted } \boldsymbol{R} \\
\text { Square }\end{array}$ \\
\hline $\begin{array}{l}\text { Motivasi } \\
\text { Kerja }\end{array}$ & 0,495 & 0.245 & $\mathbf{. 2 2 7}$ \\
\hline $\begin{array}{l}\text { Kinerja } \\
\text { Karyawan }\end{array}$ & 0,446 & 0.199 & $\mathbf{. 1 8 0}$ \\
\hline
\end{tabular}

Berdasarkan Tabel 9 diatas dapat diketahui bahwa hasil regresi menghasilkan nilai korelasi berganda (R) sebesar 0,941. Selain itu, nilai koefisien determinasi berganda $\left(\mathrm{R}^{2}\right)$ sebesar 0,444 , berarti motivasi kerja dan kinerja karyawan lapangan PT. United Sindo Perkasa dipengaruhi oleh kompensasi finansial dan kompensasi non finansial, yaitu sebesar $44,4 \%$, sedangkan sisanya yaitu $55,6 \%$ dipengaruhi oleh variabel lain yang tidak diteliti dalam penelitian ini.

\section{Hasil Uji t (Parsial)}

Uji $t$ digunakan untuk menguji pengaruh variabel independen secara persial terhadap variabel dependen. Untuk jelas dapat dilihat pada Tabel 10 berikut ini

\begin{tabular}{c|l|c|c}
\multicolumn{4}{c}{ Tabel 10. Hasil Uji t (Parsial) } \\
\hline $\begin{array}{c}\text { Dependen } \\
(Y)\end{array}$ & $\begin{array}{c}\text { Independen } \\
(\mathbf{X})\end{array}$ & t hitung & t tabel \\
\hline \multirow{2}{*}{$\begin{array}{c}\text { Motivasi } \\
\text { Kerja }\end{array}$} & $\begin{array}{l}\text { Kompensasi } \\
\text { Finansial }\end{array}$ & 3,203 & 166,320 \\
\cline { 2 - 4 } & $\begin{array}{l}\text { Kompensasi } \\
\text { Non Finansial }\end{array}$ & 2,781 & 166,320 \\
\hline Kinerja & (Constant) & 8.547 & \\
\hline
\end{tabular}

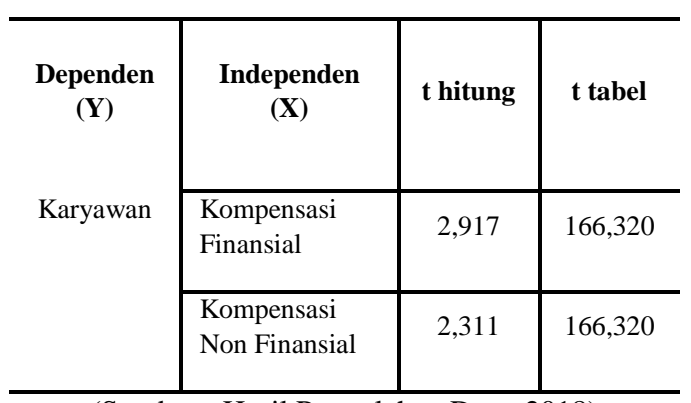

(Sumber : Hasil Pengolahan Data, 2018)

Berdasarkan Tabel 10 diatas diketahui hasil $\mathrm{Uji} \mathrm{t}$ pada variabel kompensasi finansial memiliki nilai $t_{\text {hitung }}$ $(3,203)>t_{\text {tabel }}(1,66)$ yang berarti terdapat pengaruh secara parsial terhadap variabel motivasi kerja. Hasil Uji t pada varaibel kompensasi non finansial memiliki nilai $t_{\text {hitung }}(2,781)>t_{\text {tabel }}(1,66)$ yang berarti terdapat pengaruh secara parsial terhadap variabel motivasi kerja. Hasil Uji t pada Uji t pada varaibel kompensasi non finansial memiliki nilai $t_{\text {hitung }}(2,311)>t_{\text {tabel }}(1,66)$ yang berarti terdapat pengaruh secara parsial terhadap variabel motivasi.

\section{Hasil Uji F (Simultan)}

Hasil pengujian hipotesis yang menyebabkan ada pengaruh secara simultan antara kompensasi finansial dan kompensasi non finansial terhadap motivasi kerja dan kinerja karyawan lapangan dapat di lihat pada tabel berikut ini :

Tabel 11. Hasil Uji F (Simultan)

\begin{tabular}{c|c|c}
\hline \multicolumn{2}{c|}{ Tabel 11. Hasi Uji F (Simultan) } \\
\hline \multirow{2}{*}{ Motivasi } & Df & \multirow{2}{*}{13,451} \\
\cline { 2 - 2 } & 83 & \\
\cline { 2 - 2 } & 85 & \multirow{2}{*}{10,312} \\
\hline \multirow{2}{*}{ Kinerja } & 2 & \\
\cline { 2 - 2 } & 83 & \\
\cline { 2 - 2 } & 85 & \\
\hline
\end{tabular}

\section{KESIMPULAN DAN SARAN Kesimpulan}

Berdasarkan hasil penelitian mengenai pengaruh kompensasi finansial dan kompensasi non finansial terhadap 
motivasi kerja dan kinerja karyawan lapangan pada PT. United Sindo Perkasa, dapat ditarik kesimpulan yang sesuai dengan perumusan masalah sebagai berikut:

1.Hasil penelitian menunjukkan adanya pengaruh kompensasi finansial $\left(\mathrm{X}_{1}\right)$ yang positif dan signifikan terhadap motivasi kerja $\left(\mathrm{Y}_{1}\right)$ karyawan lapangan pada PT. United Sindo Perkasa. Berdasarkan uji regresi yang telah peneliti lakukan menunjukkan bahwa hasil perhitungan $t_{\text {hitung }}(3,203)$ lebih besar dari $t_{\text {tabel }}(1,66)$ dengan tingkat signifikan t sebesar 0,002 dan nilai alpha 0,05 . Karena nilai signifikan $\mathrm{t}<$ nilai alpha $(0,002<0,05)$.

2.Hasil penelitian menunjukkan adanya pengaruh kompensasi non finansial $\left(\mathrm{X}_{2}\right)$ yang positif dan signifikan terhadap motivasi kerja $\left(\mathrm{Y}_{1}\right)$ karyawan lapangan pada PT. United Sindo Perkasa. Berdasarkan uji regresi yang telah peneliti lakukan menunjukkan bahwa hasil perhitungan $t_{\text {hitung }}(2,781)$ lebih besar dari $t_{\text {tabel }}(1,66)$ dengan tingkat signifikan t sebesar 0,007 dan nilai alpha 0,05 . Karena nilai signifikan $\mathrm{t}<$ nilai alpha $(0,007<0,05)$.

3.Hasil penelitian menunjukkan adanya pengaruh kompensasi finansial $\left(\mathrm{X}_{1}\right)$ dan kompensasi non finansial $\left(\mathrm{X}_{2}\right)$ secara simultan terhadap motivasi kerja (Y1) karyawan lapangan pada PT. United Sindo Perkasa. Berdasarkan uji regresi yang telah peneliti lakukan menunjukkan bahwa hasil perhitungan $F_{\text {hitung }}(13,451)$ lebih besar dari $\mathrm{F}_{\text {tabel }}(1,66)$.

4.Hasil penelitian menunjukkan adanya pengaruh kompensasi finansial $\left(\mathrm{X}_{1}\right)$ yang positif dan signifikan terhadap kinerja karyawan $\left(\mathrm{Y}_{2}\right)$ lapangan pada PT. United Sindo Perkasa. Berdasarkan uji regresi yang telah peneliti lakukan menunjukkan bahwa hasil perhitungan $t_{\text {hitung }}(2,917)$ lebih besar dari $t_{\text {tabel }}(1,66)$ dengan tingkat signifikan $t$ sebesar 0,005 dan nilai alpha 0,05 . Karena nilai signifikan $\mathrm{t}<$ nilai alpha $(0,005<0,05)$.

5.Hasil penelitian menunjukkan adanya pengaruh kompensasi non finansial $\left(\mathrm{X}_{2}\right)$ yang positif dan signifikan terhadap kinerja karyawan $\left(\mathrm{Y}_{2}\right)$ lapangan pada PT. United Sindo Perkasa. Berdasarkan uji regresi yang telah peneliti lakukan menunjukkan bahwa hasil perhitungan $\mathrm{t}_{\text {hitung }}(2,311)$ lebih besar dari $\mathrm{t}_{\text {tabel }}(1,66)$ dengan tingkat signifikan t sebesar 0,023 dan nilai alpha 0,05 . Karena nilai signifikan $\mathrm{t}<$ nilai alpha $(0,023<0,05)$.

6.Hasil penelitian menunjukkan adanya pengaruh kompensasi finansial $\left(\mathrm{X}_{1}\right)$ dan kompensasi non finansial $\left(\mathrm{X}_{2}\right)$ secara simultan terhadap kinerja $\left(\mathrm{Y}_{2}\right)$ karyawan lapangan pada PT. United Sindo Perkasa. Berdasarkan uji regresi yang telah peneliti lakukan menunjukkan bahwa hasil perhitungan $F_{\text {hitung }}(10,312)$ lebih besar dari $\mathrm{F}_{\text {tabel }}(1,66)$.

\section{Saran}

Berdasarkan kesimpulan di atas, dapat dikemukakan beberapa saran yang diharapkan dapat bermanfaat bagi perusahaan maupun bagi pihak-pihak lain. Adapun saran yang diberikan, antara lain :

1.Diharapkan pihak perusahaan dapat mempertahankan serta meningkatkan standar pemberian kompensasi finansial kepada karyawan lapangan, karena variabel kompensasi finansial mempunyai pengaruh yang signifikan terhadap motivasi kerja dan kinerja karyawan lapangan.

2.Variabel kompensasi non finansial juga harus dipertahankan dan dikembangkan lebih baik lagi untuk karyawan lapangan agar variabel tersebut tidak hanya menjadi pelengkap dari proses pemberian balas jasa kepada karyawan lapangan dikarenakan hal ini mempunyai pengaruh yang besar terhadap motivasi kerja dan kinerja karyawan lapangan.

\section{Keterbatasan}

Dalam penelitian ini, masih memiliki beberapa keterbatasan antara lain: 1. Penelitian ini hanya fokus pada 4 variabel saja dengan 2 variabel independen dan 2 variabel dependen 
Novi Indriani \& Adhitomo W, Pengaruh Kompensasi Finansial dan non Finansial...

sehingga untuk kedepannya dapat menambah variabel dan jumlah sampel yang lebih banyak dari peneliti untuk menambah pengetahuan. Seperti : budaya organisasi dan komitmen organisasional.

2. Keterbatasan dalam mengambil sampel yang digunakan hanya diwakili oleh karyawan lapangan saja, sehingga tidak mencerminkan perusahaan secara luas dan reaksi dari keseluruhan karyawan yang bekerja di PT United Sindo Perkasa. Serta sampel yang digunakan sebaiknya juga lebih banyak dari pada sampel dalam penelitian ini.

\section{DAFTAR PUSTAKA}

Afrida, Z., Sunuharyo, B.S., \& Astuti, E.S. (2014). Pengaruh Kompensasi Finansial dan Non Finansial terhadap Motivasi Kerja dan Kinerja Karyawan. Jurnal Administrasi Bisnis (JAB), 12, 3-9.

Algifari. (2015). Statistika Deskriptif plus untuk ekonomi dan bisnis (Cetakan Ketiga). Yogyakarta: UPP STIM YKPN.

Gunawan, Andreas Aldo \& HP. Sunardi. (2016). Pengaruh Kompensasi Dan Disiplin Kerja Terhadap Kinerja Karyawan Pada Pt Gesit Nusa Tangguh. Jurnal Ilmiah Manajemen Bisnis, Vol. 16, no. 1.

Gunawan, Monica Aprillia. (2015). Pengaruh Kompensasi Finansial Dan Non-Finansial Terhadap Motivasi Kerja Karyawan PT. Freight Express Surabaya. AGORA Vol. 3, No. 1.

Hati, Shinta Wahyu \& Indira Brahmana. (2016). Pengaruh kompensasi finansial terhadap kinerja Karyawan dengan motivasi kerja sebagai Variabel intervening pada kantor pusat PT. Citra buana prakarsa. Jurnal Inovasi dan Bisnis, Vol. 4, No. 2
Irawan, Danny Hendra. (2014). Pengaruh Kompensasi Finansial Dan Kompensasi Non Finansial Terhadap Kinerja (Studi pada Agen AJB Bumiputera 1912 Kantor Cabang Blitar). Jurnal Administrasi Bisnis (JAB). Vol. 13 No. 1.

Laminingrum, Anny Kusumo. (2016). Pengaruh Kompensasi Terhadap Motivasi Kerja Pada Karyawan Biro Pelayanan Sosial Dasar Di Sekretariat Daerah Provinsi Jawa Barat. $e$ Proceeding of Management : Vol.3, No.2.

Lenni, Nor. (2014). Pengaruh Kompensasi Finansial dan Nonfinansial Terhadap Kinerja Karyawan PT. Pertamina EP Bunyu Field kabupaten Bulungan. eJournal Ilmu Administrasi Bisnis, 2 (4) : $513-526$.

Leonardo, Edrick dan Fransisca A. (2015). Pengaruh Pemberian Kompensasi Terhadap Kinerja Karyawan Pada PT. Kopanitia. AGORA Vol. 3, No.2.

Nabiila, Nadaa. (2017). Pengaruh Kompensasi Finansial Dan Kompensasi Nonfinansial Terhadap Kinerja Karyawan Pada PT. PLN (Persero) Distribusi Lampung. Universitas Lampung.

Prabandani, Hana Savitri. (2015). Presepsi Karyawan tentang Kompensasi Finansial dan Nonfinansial terhadap Motivasi Kerja Karyawan. Skripsi. Wilayah Yogyakarta. Universitas Sanata Dharma.

Suseno, Eta Setyawan. (2014). Pengaruh Kompensasi Finansial Dan Non Finansial Terhadap Kinerja Karyawan (Studi pada Bank Rakyat Indonesia Cabang Jember). Jurnal Administrasi Bisnis (JAB). Vol.8 No.2. 